\title{
Molecular Shots
}
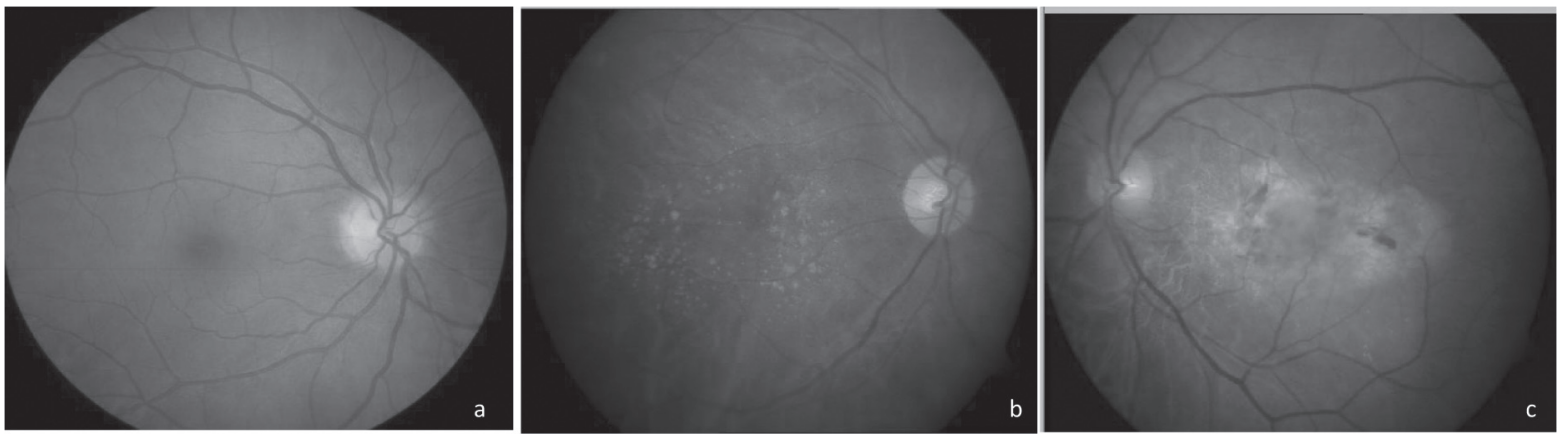

Fundus photographs of human eyes: a) Normal eye b) Eye with dry Age related macular degeneration (c) Eye with wet AMD Age related macular degeneration

by Raman Deep Singh, Neel Kamal Sharma, et al. Department of Ophthalmology and Neuroscience Research lab, PGIMER, Chandigarh

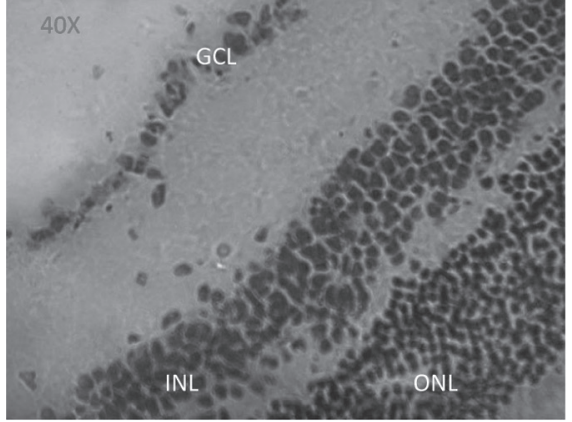

A

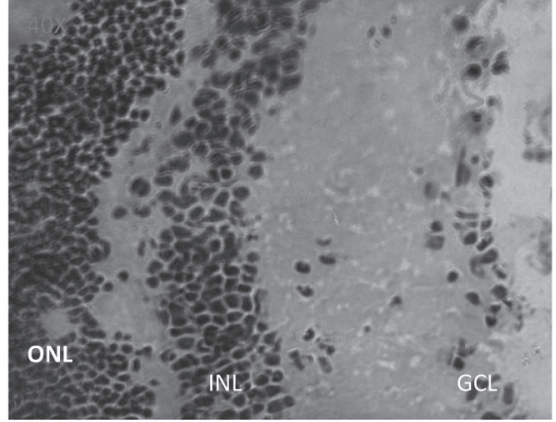

B

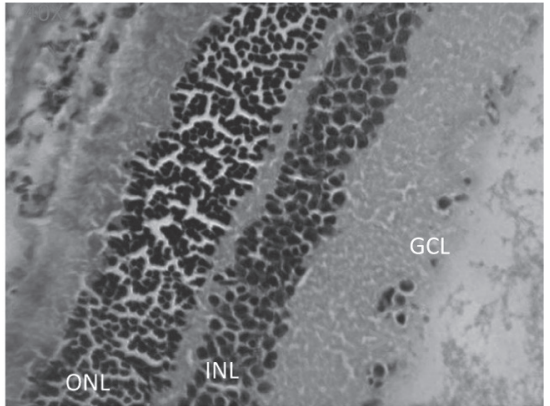

$\mathrm{C}$

Histopathology of NMDA injured mouse retina, A. Control, B. 50mM NMDA, C. 100mM NMDA, $>$ Indicates the ganglion cell disruption

by Neeru Jindal et al. Neuroscience Research lab, PGIMER, Chandigarh, INDIA 